\title{
Productivity Dynamics of Groundnut as Influenced by Different Plant Densities and Fertilizer Levels During Summer Season
}

\author{
Shailesh S. Khillare*, P. V. Mahatale, S. D. Hiwale, N. K. Darekar, \\ S. T. Dangore and W. V. More
}

Oilseed Research Unit, Dr. Panjabrao Deshmukh Krishi Vidyapeeth, Akola (M.S.), India

*Corresponding author

\begin{tabular}{l} 
K e y w o r d s \\
$\begin{array}{l}\text { Ground nut, plant } \\
\text { density, fertilizer } \\
\text { level, summer }\end{array}$ \\
Article Info \\
$\begin{array}{l}\text { Accepted: } \\
\text { 20 February } 2020 \\
\text { Available Online: } \\
\text { 10 March } 2020\end{array}$ \\
\hline
\end{tabular}

\author{
A B S T R A C T
}

An experiment entitled Productivity dyanamics of groundnut as influenced by different plant densities and fertilizer levels during summer season was carried out during summer season of 2015 at the farm of Oilseed Research Unit, Dr. Panjabrao Deshmukh Krishi Vidyapeeth, Akola (M.S.). The treatments comprised of three spacing $30 \times 10 \mathrm{~cm}, 25 \times 10 \mathrm{~cm}$ and $20 \times 10 \mathrm{~cm}$ and three fertilizer levels $75 \%, 100 \%$ and $125 \% \mathrm{RDF} \mathrm{ha}^{-1}$. The experiment was laid out in a factorial randomized block design (FRBD) with three replications. Among three spacing, $30 \times 10 \mathrm{~cm}$ was superior over $20 \times 10 \mathrm{~cm}$ in respect of plant height $(\mathrm{cm})$, number of branches plant ${ }^{-1}$, plant spread $(\mathrm{cm})$, number of root nodules plant ${ }^{-1}$,dry matter accumulation plant ${ }^{-1}(\mathrm{~g})$, haulm yield $\left(\mathrm{kg} \mathrm{ha}^{-1}\right)$. Treatment $20 \times 10 \mathrm{~cm}$ was superior over $30 \times 10 \mathrm{~cm}$ in respect to pod yield $\left(3038 \mathrm{Kg} \mathrm{ha}^{-1}\right)$, biological yield $(6993 \mathrm{~kg}$ $\mathrm{ha}^{-1}$ ) and Harvest index (42.50\%). The growth and yield attributes showed significantly increased when use of $125 \% \mathrm{RDF} \mathrm{ha}^{-1}$. Pod yield $\left(2809 \mathrm{Kg} \mathrm{ha}^{-1}\right)$, haulm yield ( $4248 \mathrm{Kg} \mathrm{ha}^{-1}$ ) obtained was significantly higher at application of 125 $\%$ RDF ha ${ }^{-1}$ than $75 \%$ and $100 \%$ RDF ha ${ }^{-1}$. Use of $125 \% \mathrm{RDF} \mathrm{ha}^{-1}$ was found to most economical than $75 \%$ and $100 \%$ RDF.

\section{Introduction}

Groundnut (Arachis hypogea L.) or peanut commonly called as poor man`s nut is an important oilseed cum legume crop of India. Groundnut belongs to $\mathrm{C}_{3}$ plant, it needs good sunshine and high temperature to produce more pods. India ranks second in production of groundnut after China. At the global level, 50 per cent of the groundnut produced is used for oil extraction, 37 per cent for confectionary and 12 per cent for seed purpose.

Where as in India, 80 per cent of the groundnut produced is used for oil extraction, 11 per cent as seed, 8 per cent used as direct food and only 1 per cent of groundnut is exported. The by-product of this crop like haulm is rich in protein content (10-12\%) and 
used as nutritious feed for cattle. As groundnut belongs to fabaceae family which maintains the soil fertility by fixing the atmospheric nitrogen which fulfils its requirement. According to the national economic survey, Indian adult could consume $7.2 \mathrm{~kg}$ year $^{-1}$ capita $^{-1}$ i.e. $20 \mathrm{~g}$ oil per day against $55 \mathrm{~g} \mathrm{day}^{-1}$ capita $^{-1}$ in western countries.

The growth rate of oilseed crops in terms of production was much higher after 1980's as compared to other crops with the introduction of technology mission on oilseeds (TMO) in 1986 and it brought "Yellow Revolution" in oilseed crops in India. Groundnut is a cash crop and it is useful for crop rotation. It is easy to grow, withstand drought to some extent and hence a choice crop for dry farming.

It is a soil erosion resisting crop. Being leguminous crop it can fix atmospheric nitrogen with the help of symbiotic relationship of bacteria in root nodules and there by reduces fertilizer requirement of succeeding crop. Thus maintain soil fertility. All parts of the plant can be commercially used. Commercially and nutritionally it is a very important source of oil. Groundnut contains 13 different vitamins (including A, the $\mathrm{B}$ group $\mathrm{C}$ and $\mathrm{E}$ ) along with 26 essential trace minerals, including calcium and iron.

\section{Materials and Methods}

The field experiment was conducted during summer season of 2015 at the Oilseed Research Unit, Dr. Panjabrao Deshmukh Krishi Vidhyapeeth, Akola during summer 2014-15. The topography of the experimental field was uniform leveled and well drained. The meteorological data indicated that the maximum temperature ranged between $23.7^{\circ} \mathrm{C}$ to $42.9^{\circ} \mathrm{C}$ and was observed at $1^{\text {th }}$ and $19^{\text {th }}$ meteorological week.
Whereas, minimum temperature ranged from $11.0^{\circ} \mathrm{C}$ to $27.8^{\circ} \mathrm{C}$ and it was registered at $1^{\text {th }}$ and $21^{\text {th }}$ meteorological week respectively. The total rainfall of $80.02 \mathrm{~mm}$ was received in 6 rainy days during the experimentation. The minimum and maximum sunshine hours was ranged from 8.2 to 9.8 hours.

The maximum and minimum wind velocity also ranged from 4.2 to $90 \mathrm{~km} \mathrm{hr}^{1}$ during the period of experiment. The assured irrigation facilities were therefore needed for growing crops during summer. The soil of experimental site was clay loam in texture, low in available nitrogen (146 kg ha $\mathrm{kg}^{-1}$, medium in available phosphorus $\left(16 \mathrm{~kg} \mathrm{ha}^{-1}\right)$ and fairly rich in available potassium $(290 \mathrm{~kg}$ $\mathrm{ha}^{-1}$ ).

The soil was moderately alkaline in reaction (pH 8.1) with EC $\left(0.45 \mathrm{dSm}^{-1}\right)$. It was moderately high in organic carbon. The experiment was laid out in Factorial Randomized Block design with three replications. Nine treatment combinations were formed with a view to integration of three planting densities and three fertilizer levels.

TAG-24 variety was used for sowing. The groundnut kernels were treated with biofertilizers like Rhizobium and PSB culture @ $250 \mathrm{~g}$ per $10 \mathrm{~kg}$ seeds. Single seed was dibble hill ${ }^{-1}$ by maintaining spacing according to treatments viz., $30 \mathrm{~cm}$ x $10 \mathrm{~cm}$ (PP @ 3.33 lakh ha ${ }^{-1}$ ), 25 x $10 \mathrm{~cm}$ (PP @ 4.00 lakh ha ${ }^{-1}$ ) and $20 \times 10 \mathrm{~cm}$ (PP @ 5.00 lakh ha ${ }^{-1}$ ) and three fertilizer levels $75 \%, 100 \%$ and $125 \%$ RDF $\mathrm{ha}^{-1}$. The lines were marked with the help of marker and sowing of the crop was done on $21^{\text {th }}$ January, 2015.

The recommended dose of fertilizer i.e. $25 \mathrm{~kg}$ $\mathrm{N}$ through urea and $50 \mathrm{Kg}_{2} \mathrm{O}_{5}$ ha- $^{1}$ through single super phosphate and $30 \mathrm{~kg} \mathrm{~K}$ through muriate of potash was applied as a basal dose. 
The correct quantity to be applied in each treatment was calculated on the basis of nutrient content of fertilizer used.

\section{Results and Discussion}

\section{Plant population}

The initial and final (at harvest) plant stand $\mathrm{ha}^{-1}$ as influenced by various treatments are compiled in Table 1.

\section{Effect of planting densities}

The plant population under study exhibited significant difference amongst themselves at initial stage and at harvest. However, these differences due to different plant spacing.

\section{Effect of fertilizer levels}

The plant population under study neither exhibited significant difference at initial stage nor at harvest due to different fertilizer levels.

\section{Growth attributes}

The data pertaining to mean growth attributes of groundnut as influenced by different treatments at harvest during summer 2015 are presented in Table 2.

\section{Effect of plant densities}

The growth attributes viz., plant height $(\mathrm{cm})$, plant spread $(\mathrm{cm})$, number of branches plant ${ }^{-1}$, number of nodules plant ${ }^{-1}$ and dry matter plant $^{-1}(\mathrm{~g})$ were found to be significant difference due to plant densities at harvest. In $S_{1}$ spacing $(30 \times 10 \mathrm{~cm})$ verified maximum growth attributes viz., plant height (15.81 $\mathrm{cm})$, plant spread $(32.04 \mathrm{~cm})$, number of branches plant ${ }^{-1}(6.15)$, number of nodules plant $^{-1}(25.78)$ and dry matter plant ${ }^{-1}(24.25 \mathrm{~g})$ which was significantly superior over spacing $S_{2}(25 \times 10 \mathrm{~cm})$ and spacing $S_{3}(20 \times 10 \mathrm{~cm})$.
The increase in growth attributes in $S_{1}$ spacing $(30 \times 10 \mathrm{~cm})$ might be due to less plants competition for nutrients, water and space. Denser plant population has less availability of macro and micro nutrients and hence less plant height as compare to low plant population. Above results are in agreement with findings of Migawer et al., (2000) and Kausale et al., (2002)

\section{Effect of fertilizer levels}

The growth attributes viz., plant height $(\mathrm{cm})$, plant spread $(\mathrm{cm})$, number of branches plant ${ }^{-1}$, number of nodules plant ${ }^{-1}$ and dry matter plant $^{-1}(\mathrm{~g})$ were not found significant at harvest stages. However numerically high value of growth attributes viz., plant height $(15.06 \mathrm{~cm})$, plant spread $(31.08 \mathrm{~cm})$, number of branches plant ${ }^{-1}(5.87)$, number of nodules plant $^{-1}(26.56)$ and dry matter plant ${ }^{-1}(24.12 \mathrm{~g})$ was recorded with treatment $\mathrm{F}_{3}(125 \% \mathrm{RDF})$ and treatment $\mathrm{F}_{1}(75 \% \mathrm{RDF})$ recorded minimum growth attributes viz., plant height $(14.68 \mathrm{~cm})$, plant spread $(29.85 \mathrm{~cm})$, number of branches plant ${ }^{-1}(5.42)$, number of nodules plant $^{-1}(25.78)$ and dry matter plant ${ }^{-1}(23.63$ g). Similar results were reported by Sable (2002), Thakre et al., (2003) and Throve and Dhonde (2007).

\section{Effect of planting densities}

The yield of groundnut viz., pod yield ( $\mathrm{kg} \mathrm{ha}^{-}$ ${ }^{1}$ ), haulm yield $\left(\mathrm{kg} \mathrm{ha}^{-1}\right)$, biological yield $(\mathrm{kg}$ $\mathrm{ha}^{-1}$ ) and harvest index due to different planting densities was found to be significant at harvest. The crop grown with spacing $\mathrm{S}_{3}$ $(20 \times 10 \mathrm{~cm})$ shows more yield of groundnut viz., pod yield (3038 $\left.\mathrm{kg} \mathrm{ha}^{-1}\right)$, biological yield $\left(6993 \mathrm{~kg} \mathrm{ha}^{-1}\right)$ and harvest index (42.58 $\%$ )than other treatments of spacing viz., $\mathrm{S}_{2}$ $(25 \times 10 \mathrm{~cm})$ and the crop grown with spacing $\mathrm{S}_{1}(30 \times 10 \mathrm{~cm})$. This might be happened due to the effect of planting densities, high plant densities has more number of plant as 
compare to low plant densities and hence per plant yield may be less but due to the effect of high plant density per hectare yield was recorded more. The haulm yield $\mathrm{kg} \mathrm{ha}^{-1}$ due to different planting densities was found to be significant at harvest. The crop grown with treatment $S_{1} \quad(30 \quad x \quad 10 \quad \mathrm{~cm})$ recorded significantly highest haulm yield $(4391 \mathrm{~kg}$ ha $\left.{ }^{1}\right)$ than spacing $S_{2}$ and spacing $S_{3}$ which was at par with each other. This might be happened due to the effect of planting densities, high plant densities has more competition for nutrients and hence less dry matter accumulation per plant takes place per hectare as compare to low plant densities. Above results obtained are in agreement with the findings of Rama Jyoti et al., (2004) and Ghosh et al., (2005).

\section{Effect of fertilizer levels}

The yield of groundnut viz., pod yield ( $\mathrm{kg} \mathrm{ha}$ $\left.{ }^{1}\right)$, haulm yield $\left(\mathrm{kg} \mathrm{ha}^{-1}\right)$ and biological yield $\left(\mathrm{kg} \mathrm{ha}^{-1}\right)$ due to the different fertilizer levels was found significant at harvest. The treatment $\mathrm{F}_{3}(125 \% \mathrm{RDF})$ recorded more yield of groundnut viz., pod yield $(2809 \mathrm{~kg}$ $\left.\mathrm{ha}^{-1}\right)$, haulm yield (4248 $\left.\mathrm{kg} \mathrm{ha} \mathrm{ha}^{-1}\right)$ and biological yield (7001 $\mathrm{kg} \mathrm{ha}^{-1}$ ) and found significantly superior over $\mathrm{F}_{1}(75 \% \mathrm{RDF})$ and
$\mathrm{F}_{2}(100 \% \mathrm{RDF})$. Treatment $\mathrm{F}_{1}(75 \% \mathrm{RDF})$ recorded minimum yield of groundnut viz., pod yield (2376 kg ha ${ }^{-1}$ ), haulm yield (4059 $\mathrm{kg} \mathrm{ha}^{-1}$ ) and biological yield (6435 $\left.\mathrm{kg} \mathrm{ha}^{-1}\right)$.

This might be due to less availability of nutrients in treatment $\mathrm{F}_{1}$ as compare to treatment $\mathrm{F}_{3}$ and hence shows less pod yield $\mathrm{kg} \mathrm{ha}{ }^{-1}$. Above results obtained are in agreement with the findings of Rajnikanth et al., (2008), Elayraja and Singarvel (2009) and Karunakaran et al., (2010). The harvest index due to different fertilizer levels was found to be non-significant. However, the crop grown with treatment $\mathrm{F}_{3}(125 \% \mathrm{RDF})$ shows more value of harvest index (39.22\%). Treatment $\mathrm{F}_{1}(75 \% \mathrm{RDF})$ shows less value of harvest index $(36.86 \%)$.

This might be happened due to the effect of different doses of fertilizer, high fertilizer levels has more availability of nutrients as compare to low fertilizer levels and hence results in maximum dry matter production per plant and ultimately more dry matter production per hectare results in more biological yield and harvest index in high fertilizer levels. Above results obtained are in agreement with the findings of Nwokwu (2006).

Table.1 Emergence and final plant stand $\mathrm{ha}^{-1}$ as influenced by different treatments

\begin{tabular}{|c|c|c|}
\hline \multirow[b]{2}{*}{ Treatments } & \multicolumn{2}{|c|}{ Plant count $\left(\mathrm{ha}^{-1}\right)$} \\
\hline & Initial & Final \\
\hline \multicolumn{3}{|l|}{ Planting densities } \\
\hline$S_{1}-30 \times 10 \mathrm{~cm}\left(3.33\right.$ lakh ha $\left.{ }^{-1}\right)$ & 327513 & 321825 \\
\hline$S_{2}-25 \times 10 \mathrm{~cm}\left(4\right.$ lakh ha $\left.{ }^{-1}\right)$ & 378968 & 373015 \\
\hline$S_{3}-20 \times 10 \mathrm{~cm}\left(5\right.$ lakh ha $\left.{ }^{-1}\right)$ & 478703 & 472222 \\
\hline S.E. $(\mathbf{m}) \pm$ & 4606 & 4995 \\
\hline C D at $5 \%$ & 13810 & 14977 \\
\hline \multicolumn{3}{|l|}{ Fertilizer levels } \\
\hline$F_{1}-75 \%$ of RDF & 388227 & 381481 \\
\hline$F_{2}-100 \%$ of RDF & 400132 & 393518 \\
\hline$F_{3}-125 \%$ of RDF & 396825 & 392063 \\
\hline S.E. $(\mathbf{m}) \pm$ & 4606 & 4995 \\
\hline C D at $5 \%$ & NS & NS \\
\hline
\end{tabular}


Table.2 Mean growth attributes of groundnut as influenced by different treatments at harvest

\begin{tabular}{|c|c|c|c|c|c|}
\hline \multirow[b]{2}{*}{ Treatments } & \multicolumn{5}{|c|}{ Growth attributes } \\
\hline & $\begin{array}{l}\text { Plant } \\
\text { height } \\
\text { (cm) }\end{array}$ & $\begin{array}{l}\text { Plant } \\
\text { spread } \\
(\mathrm{cm})\end{array}$ & $\begin{array}{c}\text { No. of } \\
\text { branches }^{-} \\
\text {Plant }^{-1}\end{array}$ & $\begin{array}{c}\text { No of } \\
\text { nodules }^{-1} \\
\text { Plant }^{-1}\end{array}$ & $\begin{array}{c}\text { Dry matter } \\
\text { Plant }^{-1} \\
\text { (gm) }\end{array}$ \\
\hline \multicolumn{6}{|l|}{ Planting densities } \\
\hline$S_{1}-30 \times 10 \mathrm{~cm}\left(3.33\right.$ lakh ha $\left.^{-1}\right)$ & 15.81 & 32.04 & 6.15 & 25.78 & 24.25 \\
\hline$S_{2}-25 \times 10 \mathrm{~cm}\left(4\right.$ lakh ha $\left.{ }^{-1}\right)$ & 14.94 & 29.38 & 5.90 & 25.67 & 24.19 \\
\hline$S_{3}-20 \times 10 \mathrm{~cm}\left(5\right.$ lakh ha $\left.^{-1}\right)$ & 14.02 & 28.31 & 4.87 & 25.00 & 23.02 \\
\hline S.E. $(m) \pm$ & 0.15 & 0.29 & 0.19 & 0.49 & 0.19 \\
\hline C D at $5 \%$ & 0.44 & 0.86 & 0.56 & NS & 0.56 \\
\hline \multicolumn{6}{|l|}{ Fertilizer levels } \\
\hline$F_{1}-75 \%$ of RDF & 14.68 & 29.85 & 5.42 & 25.78 & 23.63 \\
\hline$F_{2}-100 \%$ of RDF & 15.03 & 30.80 & 5.63 & 24.11 & 23.71 \\
\hline$F_{3}-125 \%$ of RDF & 15.06 & 31.08 & 5.87 & 26.56 & 24. 12 \\
\hline S.E. $(\mathbf{m}) \pm$ & 0.15 & 0.29 & 0.19 & 0.49 & 0.19 \\
\hline C D at $5 \%$ & NS & NS & NS & NS & NS \\
\hline
\end{tabular}

Table.3 Mean yield of groundnut as influenced by different treatments at harvest

\begin{tabular}{|c|c|c|c|c|}
\hline Treatments & $\begin{array}{l}\text { Pod yield } \\
\left(\mathrm{kg} \mathrm{ha}^{-1}\right)\end{array}$ & $\begin{array}{l}\text { Haulm yield } \\
\qquad\left(\mathrm{kg} \mathrm{ha}^{-1}\right)\end{array}$ & $\begin{array}{c}\text { Biological } \\
\text { yield (kg ha') }\end{array}$ & $\begin{array}{l}\text { Harvest } \\
\text { index }\end{array}$ \\
\hline \multicolumn{5}{|l|}{ Planting densities } \\
\hline $\mathrm{S}_{1}-30 \times 10 \mathrm{~cm}\left(3.33\right.$ lakh ha $\left.^{-1}\right)$ & 2275 & 4391 & 6667 & 34.09 \\
\hline$S_{2}-25 \times 10 \mathrm{~cm}\left(4\right.$ lakh ha $\left.^{-1}\right)$ & 2479 & 4135 & 6615 & 37.40 \\
\hline $\mathrm{S}_{3}-20 \times 10 \mathrm{~cm}\left(5 \mathrm{lakh} \mathrm{ha}^{-1}\right)$ & 3038 & 4009 & 6993 & 42.58 \\
\hline S.E. $(\mathrm{m}) \pm$ & 83.69 & 48.11 & 111.92 & 0.83 \\
\hline $\mathrm{CD}$ at $5 \%$ & 250.90 & 144.23 & 335.76 & 2.48 \\
\hline \multicolumn{5}{|l|}{ Fertilizer levels } \\
\hline $\mathrm{F}_{1}-75 \%$ of $\mathrm{RDF}$ & 2376 & 4059 & 6435 & 36.86 \\
\hline $\mathrm{F}_{2}-100 \%$ of RDF & 2608 & 4229 & 6838 & 37.99 \\
\hline $\mathrm{F}_{3}-125 \%$ of RDF & 2809 & 4248 & 7001 & 39.22 \\
\hline S.E. $(\mathrm{m}) \pm$ & 83 & 48 & 111.92 & 0.83 \\
\hline $\mathrm{CD}$ at $5 \%$ & 250.90 & 144.23 & 335.55 & NS \\
\hline
\end{tabular}

The growth and yield attributes found maximum when crop grown with spacing $\mathrm{S}_{1}$ $30 \mathrm{~cm}$ x $10 \mathrm{~cm}$ (Plant Population@3.33 lakh $\mathrm{ha}^{-1}$ ) over other plant spacing. The growth and yield attributes recorded maximum with treatment $\mathrm{F}_{3}(125 \% \mathrm{RDF})$.

\section{Acknowledgment}

The authors duly acknowledge the Head and Advisory committee Department of Agronomy for research work and technical support related to the research.

\section{References}

Elayaraja, D. and R. Singaravel 2009. Effect of organic wastes and NPK levels on nutrient uptake and yield of groundnut in coastal sandy soil Madras Agric. J. 96 (7-12): 362-364.

Ghosh, P.K., and Dayal Devi. 2005. Optimization of date of sowing in a new groundnut-wheat relay cropping in 
semi-arid tropics of India. J.Sustainable Agric. 26(3): 83-94.

Karunakaran, V. J., Rammohan, V. Chellamuthu and R. Poonghuzhalan 2010. Effect of integrated nutrient management on the growth and yield of groundnut in costal region of Karaikal. Indian J. Agron. 55(2)128-132

Kausale, S.P., S.B. Shinde, L.K. Patel and N.S. Borse 2002. Effect of integrated nutrient management on nodulation, dry matter accumulation and yield of summer groundnut at south Gujarat condition. Legume Res. 32(3):227-229.

Migawer, A., Ekram, A.M. Mona and Soliman (2000) Performance of two peanut cultivars and their response to NPK fertilization in newly reclaimed loamy sand soil. J. Agric. Sci. Mansoura Univ. 26 (11): 6653 - 6667.

Nwokwu, G.N. International research journal 2006. Influence of phosphorus and plant spacing on the growth and yield of Groundnut Department of Crop Production and Landscape Management, Faculty of Agriculture and Natural Resources Management, Ebonyi State University, Abakaliki, Nigeria.
Rajanikanth, E., M.V.R. Subrahmanyam and J.V. Rao 2008. Effect of integrated nutrient management practices on growth and yield of rainfed groundnut, Arachis hypogaea L. intercropped with guava, Psidium guajava. J. Oilseeds Res. 25 (2): 157-160.

Rama Jyothi, M., C Radha Kumari, U. Obulamma and B. Lingam 2004. Responce of early rabi groundnut to spacing, irrigation and plant protection levels. 21(1):171-172.

Sable, R.N.,2002. Studies on nitrogen source on growth and yield of kharif groundnut. J. Maharashtra agric. Univ. 27(3); 322-324.

Thakare, G.V., R.B. Ulemale, R.S. Shivankar, and A.A. Dahiphale 2003. Morphological indices and yield attributes as influenced by integrated nutrient management summer groundnut. Ann. Pl. Physiol. 17(1):1-5.

Thorave, D.S. and M.B. Dhonde 2007. Morphological indices and yield attributes as influenced by integrated nutrient management summer groundnut. Ann. Pl. Physiol.21(1):186188.

\section{How to cite this article:}

Shailesh S. Khillare, P. V. Mahatale, S. D. Hiwale, N. K. Darekar, S. T. Dangore and More. W. V. 2020. Productivity Dynamics of Groundnut as Influenced by Different Plant Densities and Fertilizer Levels During Summer Season. Int.J.Curr.Microbiol.App.Sci. 9(03): 2571-2576. doi: https://doi.org/10.20546/ijcmas.2020.903.294 